\title{
Trace element compositions of rocks and minerals from the Chilas I gneous Complex, Kohistan, northern Pakistan
}

\author{
Masumi U Mikoshiba†*, Yutaka Takahashi†, Kazuya Kubo†, Yuhei Takahashi†, Allah B Kausarłand Tahseenullah Khan‡ \\ † Institute of Geoscience, Geological Survey of Japan, AIST, 1-1-1, Higashi, Tsukuba 305-8567, JAPAN \\ ₹ Geoscience Laboratory, Geologi cal Survey of Pakistan, Chak Shahzad, P.O. Box 1461, Islamabad, PAKISTAN \\ * To whom correspondence should be addressed. E-mail: masumi-mikoshiba@aist.go.jp
}

The Kohistan terrane in the western Himalayan region is considered as a Cretaceous island-arc sequence sandwiched between the Asian and Indian continental crusts. It is a 300-kmlong plutonic body that extends parallel to the general trend of the Kohistan terrane. Rocks of this complexare petrographically and compositionallysimilar to plutonic xenolithsfound in island arcs (Khan et al. 1989). We report geochemical data of rocks and minerals in the Chilas Complex and discuss the melt compositions and magmatism in middle to lower arc crust.

The Chilas Complex is well exposed along the Indus and Swat Rivers. Most of the complex consists of generally homogeneous gabbronorite, pyroxene diorite and pyroxene quartz diorite, and thesearecalled astheMain facies rocks. Some of therockswerere-equilibrated under granulitefacies conditions at $750-850^{\circ} \mathrm{C}$ and $6-8 \mathrm{kbar}$ (Swat valley, Jan and Howie 1980).

Rocks with layered structure are also found in the Chilas Complex, which often occur in km-scale masses. Some of the masses are abundant in peridotites associated with layered gabbroicrocks (ultramafic-mafic association), which arededuced to be crystal accumulates. One of the bodies of the ultramaficmafic association, Thak bodyjust to theeast of Chilastown, shows excellent outcrops. This body isincluded in the Main facies rocks, and consists of cyclic units of layered cumulate rocks, which is classified into olivine-dominant cumulate (dunite-wehrlite), plagioclase-dominant cumulate (troctolite-gabbronorite) and pyroxene-dominant cumulate (websterite-clinopyroxenite). Hornblendeand spinel areoften included in therocks. Mgvalues of the pyroxenes and An content of plagioclase are high in these cumulative rocks, but systematic change of major chemical composition of themineralsarenot recognized through theThak body. In addition, one gabbronoritemass along the Indus River (Basehri body) is characterized by well-developed rhythmic layering, and most of the layers were overturned. The Basehri body is intruded by the Main facies rocks, which isconsidered as crystal cumulatefrom themagma of the Main facies.

Main facies rocks of the Chilas Complex have the characteristics of subduction-related calc-alkalinemagmas with depletion of $\mathrm{Nb}$ relative to other incompatible elements (Khan et al. 1989). The concentrations of $\mathrm{K}_{2} \mathrm{O}, \mathrm{Y}, \mathrm{Zr}$, Th and rare earth elements (REE) in the Main facies rocksare positively correlative with $\mathrm{SiO}_{2}$ content. In thechondrite-normalized diagram, thelight REE areenriched relativeto heavy REE in the rocks, and the REE patterns are slightly concave upward. The chemical variation of the most of the Main facies rocks can be explained by a weak segregation of melt and early-formed crystals composed of plagioclase, clinopyroxeneand orthopyroxene.

Themajor element compositions of therocksfrom theThak body show the wide variation reflecting accumulation of early- stage crystals. Rocks are generally poor in REE and other incompatible elements, implyingtheseparation of the melt and crystals areeffective. Even thegabbroic rocks without olivineare still poor in REE and other incompatibleelements relativeto the Main facies rocks. REE concentrations of thelayered rocks of the Basehri body are generally lower than those of the Main facies rocks.

For characterization of magmas of theselayered rocks, trace element compositions of clinopyroxene and plagioclase are determined by ICP-MS after mineral separation. Clinopyroxene fractions from wehrlite and websterite, and whole-rock sample of clinopyroxenite in the Thak body have REE, Ba, Nb, Sr and Zr concentrationssimilar to each other. Theclinopyroxeniteand the clinopyroxene from websterite have weak negative Eu anomaly and REE concentrations slightly higher than the clinopyroxene from wehrlite. The clinopyroxenefrom a plagioclase-rich part of the layered gabbronorite of the Basehri body shows the REE concentrations 3-5 times higher than clinopyroxenes from the Thak body, with clear negative Eu anomaly. Plagioclase fractions from a troctolite in theThak body and from the plagioclase-rich rock of the Basehri body have REE concentrations with positive Eu anomalies, and they havesimilar Sr concentrationsalthough the plagioclase from the troctolite are poor in most of the incompatibleelements.

The melts calculated from the clinopyroxenes of the pyroxene-and olivine-dominantcumulates in theThak body are enriched in light REE relative to heavy REE, showing chemical characteristics closer to calc-alkaline or high-alumina basalt magmasin island arcsrather than depleted island-arc tholeiites. The calculated melts have REE, Sr and Zr concentrations similar to theMain facies rocks. Themeltscalculated from the plagioclase fractions have $\mathrm{Sr}$, Ba and $\mathrm{Rb}$ concentrations similar to the Main facies rocks. These data suggest a possibility that the original magmas of the cumulates of the Thak body and the magma of the Main facies were derived from common or similar source materials, in spiteof large petrographic variations. Traceelement abundances in clinopyroxene and plagioclase from the Basehri body may have been affected by subsolidus equilibration, and also affected by a small amount of trapped melt.

\section{References}

Jan MQ and RA Howie. 1980. Ortho- and clinopyroxene from pyroxene granulites of Swat, Kohistan, northern Pakistan. Mineral Mag 43: 715728

Khan MA, MQ Jan, BF Windley, J Tarney and MF Thirlwall. 1989. The Chilas Mafic-Ultramafic Igneous Complex; The root of the Kohistan Island Arc in the Himalaya of northern Pakistan. Geol Soc Amer Spec Paper 232: 75-94 